\title{
Low, Controlled Nutrient Availability Provided by Organic Waste Materials for Chrysanthemum
}

\author{
Kimberly A. Williams and Paul V. Nelson ${ }^{2}$ \\ Department of Horticultural Science, North Carolina State University, Raleigh, NC 27695-7609 \\ Additional index words. Chrysanthemum $\times$ morifolium, Dendranthema $\times$ grandiflorum, plant nutrition, industrial sludge, \\ poultry manure, bonemeal, feathers, organic fertilizer
}

\begin{abstract}
Seven organic materials including 1) the bacterium Brevibacterium lactofermentum (Okumura et al.) in a nonviable state, 2) a mixture of two bacteria, Bacillus licheniformis (Weigmann) and Bacillus subtilis (Ehrenberg), plus the fungus Aspergillus niger (van Tieghem) in a nonviable state, 3) an activated microbial sludge from wastewater treatment, 4) sludge from a poultry manure methane generator, 5) unsteamed bonemeal, 6) aged pine needles, and 7) poultry feathers were evaluated to determine their pattern and term of $\mathrm{N}$ release and the possibility of using them as an integral part of root media releasing $N$ at a steady, low rate over 10 to 12 weeks for production of Dendranthema $\times$ grandiflorum (Ramat.) Kitamura 'Sunny Mandalay'. These were compared to the inorganic slowrelease fertilizer micro Osmocote $(17 \mathrm{~N}-3.9 \mathrm{P}-10.8 \mathrm{~K})$ and a weekly liquid fertilizer control. All organic sources released $\mathrm{N}$ most rapidly during the first 2 weeks, followed by a decline, which ended at 6 to 7 weeks. Brevibacterium lactofermentum, bonemeal, and micro Osmocote treatments resulted in about equal growth, which was similar to growth of a weekly liquid fertilizer control for 9 weeks in the first and for 12 weeks in the second experiment. The period of $\mathrm{N}$ release could not be extended through increased application rate of source due to the high initial release rate. It was not possible to lower source application rates to achieve an effective, low soil solution concentration due to the large variation in release rate over time. Efficiency of $\mathrm{N}$ use varied among plants grown in media treated with various microorganismal sources and was highest in those treated with $B$. lactofermentum. Nitrogen release from ground poultry feathers was inadequate, and additions of the viable hydrolyzing bacterium $B$. licheniformis to feathers failed to increase soil solution $\mathrm{N}$ levels. Attempts to retard mineralization of $B$. lactofermentum by cross-linking proteins contained within the bacterium by means of heat treatment at $116 \mathrm{C}$ vs. $82 \mathrm{C}$ failed. While anaerobic poultry manure sludge proved to be an inefficient source of $N$, it provided large amounts of $P$. Organic sources released primarily ammoniacal $\mathrm{N}$, which raised the medium $\mathrm{pH}$ by as much as one unit, necessitating the use of less limestone in the medium formulation.
\end{abstract}

In commercial greenhouse fertilization systems, $\mathrm{N}$ concentrations > $15 \mathrm{~mm}$ and correspondingly high concentrations of other nutrients are commonly achieved in the soil solution through continuous liquid fertilization or use of slow-release fertilizers. These high concentrations result in large losses of nutrients in the greenhouse effluent through leaching (Cox, 1985; Hershey and Paul, 1982), and thus in potential environmental contamination.

One possible solution to this problem is the maintenance of lower soil solution nutrient concentrations. Numerous studies conducted with continuous-replacement hydroponic systems demonstrate that plants that meet commercial growth expectations can be produced at ultra-low nutrient concentrations if the levels are constantly sustained, that is, not allowed to deplete or fluctuate greatly. As examples, Williams (1961) grew acceptable barley (Hordeum vulgare L.) in a solution culture system at $\mathrm{K}$ concentrations approaching $13 \mu \mathrm{M}$. Clement et al. (1974) found that $7.1 \mu \mathrm{M} \mathrm{N}$ was adequate for normal ryegrass (Lolium perenne L.) growth. Elliot and Nelson (1983) success-

\footnotetext{
Received for publication 12 July 1991. Accepted for publication 4 Feb. 1992. This research was funded in part by the North Carolina Agricultural Research Service (NCARS), and by grants from Ajinomoto USA, Inc. and Fisons Horticulture, Inc. Use of trade names in this publication does not imply endorsement by the NCARS of products named nor criticism of similar ones not mentioned. Appreciation is extended to Yoder Brothers, Inc., for providing chrysanthemum cuttings. Laboratory assistance of Nancy C. Mingis is gratefully acknowledged. From a thesis submitted by K.A.W. in partial fulfillment of the requirements for the MS degree. This paper was presented in part at the 87th Annual Meeting of the ASHS, Tucson, Ariz., 4-8 Nov. 1990. The cost of publishing this paper was defrayed in part by the payment of page charges. Under postal regulations, this paper therefore must be hereby marked advertisement solely to indicate this fact.

'Graduate Research Assistant.

'Professor.
}

fully grew chrysanthemums at $30 \mu \mathrm{MN}$ in a flowing-solution culture system. These studies indicated that if nutrients are replaced in the soil solution in accordance with the rate of plant removal, an ultra-low nutrient concentration in the medium is adequate for plant growth.

The above research leads one to question whether it is possible to achieve and sustain low nutrient levels in the soil solution of a commercial solid substrate production system. It is not feasible with the current technology of continuous liquid fertilization or large-pelleted slow-release fertilizers that necessitate large distances between pellets. However, a nutrient source that is an integral part of the substrate and is contained in the rhizosphere of each root might effectively establish and maintain a low, relatively constant nutrient regime in the soil solution of a commercial-style solid substrate. Ideally, the nutrient source should provide nutrients through the entire cropping cycle of a floricultural crop, a minimum of 3 months. Natural organic nutrient sources may perform well because, in addition to providing nutrients, they would substitute for root medium components, such as peatmoss, providing similar properties. Other organic materials that have traditionally been used in greenhouse fertilization include castor pumice, cottonseed meal, dried blood, and hoof and horn meal (Bunt, 1988). The former three do not have a sufficient period of $\mathrm{N}$ release. The latter source has an extended period of $\mathrm{N}$ release but is not easily obtained. Feathers have similar molecular structure and would be a good substitute for hoof and horn meal.

Various benefits would follow from a commercial system that used a low, controlled-release nutrient source. The system would be open, so it would require low capital and technological input, in contrast to a closed system such as ebb and flow, where nutrient solution is recycled. In addition, the stresses of overand underfertilizing brought on by the widely fluctuating soil 
solution concentrations of conventional fertilization methods would be reduced, and this, theoretically. could improve crop yield. Further, if an organic-waste product could be used as the nutrient source for this system, it would offer a constructive alternative disposal method for the waste and conserve the natural reserves of nutrients and/or the energy required for their production.

Therefore, the objective of this research was to assess the suitability of seven organic materials for providing steady, low concentrations of $\mathrm{N}$ over a 10- to 12-week cropping period for chrysanthemums.

\section{Materials and Methods}

General procedures. Two experiments were conducted with the following procedures in common. Rooted cuttings of pot chrysanthemum were planted, one cutting per $10-\mathrm{cm}$ standard round, green, plastic pot. The medium volume was $413 \mathrm{~cm}^{3}$, and the depth was $7.5 \mathrm{~cm}$. Root medium consisted of equal volumes of sphagnum peat and Terra-lite vermiculite (GraceSierra, Milpitas, Calif.; grade 2-coarse in Expt. 1 and grade 3-medium in Expt. 2). Root medium was amended with the following materials and rates per liter, except where noted: 5.9 g dolomitic limestone; $2.7 \mathrm{~g} 20 \%$ superphosphate; and $0.074 \mathrm{~g}$ FTE-555 micronutrient mix (Frit Industries, Ozark, Ala.). Plants received 2 weeks of long days and 9 to 10 weeks of short days and were pinched to leave nine nodes 2 weeks after planting. Terminal flower buds were removed 5 weeks later: Pots were spaced $19 \times 28 \mathrm{~cm}$. Greenhouse night and day temperatures were set at 17 and $25 \mathrm{C}$, respectively, when the season of the year permitted. Treatments were arranged in randomized complete-block designs with three blocks and four pots per experimental unit. Data were subjected to analysis of variance, and means were separated by LSD. Data for dry weight in Expt. 1 were also analyzed by linear regression analysis (PROC REG, SAS Inst., Cary, N.C.).

Root media were sampled by vacuum removal of unaltered soil solution. To accomplish this, tap water was applied to pots, allowed to equilibrate for $1.5 \mathrm{~h}$, then pots were sealed in a suction funnel and a vacuum was drawn on the base of the pot. Five milliliters of solution was collected from each of the four pots within an experimental unit, and the four then were combined to provide a 20-ml sample. Samples were drawn on a preset schedule without regard to time of water or fertilizer application. Fertilizer solution was applied weekly in both experiments. All solution samples were collected during the cycle following fertilization except once in Expt. 1 (week 6), in which plants were watered between fertilizer application and soil solution sampling.

Soil solution samples were analyzed for $\mathrm{NO}_{3}-\mathrm{N}$ (Cataldo et al., 1975), $\mathrm{NH}_{4}-\mathrm{N}$ (Chancy and Marbach, 1962), $\mathrm{PO}_{4}-\mathrm{P}$ [Chapman and Pratt (1961), for concentrations $>10 \mu \mathrm{g} \cdot \mathrm{ml}^{-1}$; and Murphy and Riley (1962), for concentrations $<10 \mu \mathrm{g} \cdot \mathrm{ml}^{-1}$ ] using a UV/VIS spectrophotometer (Perkin-Elmer, Norwalk, Corm.) Potassium, $\mathrm{Ca}$, and $\mathrm{Mg}$ were determined by atomic absorption spectroscopy, and $\mathrm{pH}$ and electrical conductivity (EC) measurements were recorded.

Tissue samples consisted of the youngest, fully expanded leaves at the midcrop and total shoots at the end of the crop. Plant tissue was rinsed under warm tap water, washed for $30 \mathrm{sec}$ in $0.2 \mathrm{~N} \mathrm{HCI}$, rinsed under warm tap water, and rinsed for $30 \mathrm{sec}$ in distilled water. Samples were ashed and analyzed by the procedures described in Fonteno and Nelson (1990).

Plant quality was assessed by ratings assigned subjectively after consideration of plant volume, form, foliage color, and number and size of flowers on a scale of 1 to 10 with 10 representing the highest quality. Plant height was measured from the rim of the pot to the top of the flower canopy. Plant width was recorded at end crop as the average of two measurements taken at right angles. Dry weight (dried for $48 \mathrm{~h}$ at 70C) of the total above-ground portion of the plant was recorded at end crop. Efficiency of $\mathrm{N}$ use was determined as biomass produced per unit of $\mathrm{N}$ applied.

Nitrogen sources were analyzed for total $\mathrm{N}$ by a semi microKjeldahl procedure in which salicylic acid was added as a pretreatment to digestion to aid in the reduction of $\mathrm{NO}_{3}$ (Eastin, 1978). Carbon : nitrogen ratios of $\mathrm{N}$ sources were determined using a PE 2400 CHN Elemental Analyzer (Perkin-Elmer, Norwalk, Corm.).

Amendments and rates of application (Expt. 1). Cuttings were planted on 2 Mar. 1989. Five materials were-tested as N sources: 1) a specific strain of the nonviable bacterium Brevibacterium lactofermentum cultured to produce a specific amino acid, designated "A"; 2) 3- to 4-month release micro Osmocote (17N3.9P-10.8K, 356 capsules/g, Grace-Sierra); 3) an activated microbial sludge mixture from a waste-water treatment process involving vitrification followed by denitrification; 4) animal feedgrade unsteamed bonemeal (particles $\leq 5.6 \mathrm{~mm}$ ); and 5) 3-yearaged pine needles. The products were incorporated into the medium described previously at the rates of $\mathrm{N}$ indicated in Table 1. Nitrogen treatment rates were originally based on analyses of sources provided by their suppliers; however, subsequent analyses (Table 1) indicated discrepancies that account for the variable rates actually applied. Bulk densities (Table 2) of the sources were determined by measuring $1000 \mathrm{~cm}^{3}$ of each product and dividing the weight (g) by this volume. Only two sources, water-treatment sludge and pine needles, were applied in sufficient quantities to affect physical properties of the medium. To compensate for the volume of these two sources, the quantities of peat and vermiculite were reduced. Two controls were employed; one received weekly liquid applications of a solution of $17 \mathrm{mM} \mathrm{NH}_{4}, 26 \mathrm{~mm} \mathrm{NO}_{3}$, and $13 \mathrm{~mm} \mathrm{~K}$ (designated + control). The second control received no nutrient root medium amendments nor any fertilizer application during crop production (designated - control). Plants in all other treatments, except those containing micro Osmocote, received a weekly application of $6.5 \mathrm{mM} \mathrm{K}_{2} \mathrm{SO}_{4}$. Plants were watered just as a few individuals began to express visible stress symptoms, and the leaching fraction (defined as volume of leachate divided by volume of irrigation solution applied) was estimated to fall within the range 0.75-0.85. The surfactant Aqua-Gro-L (Aquatrols Corp. of America, Pennsauken, N. J.) was applied to each pot as a drench 2 weeks after planting at $37.3 \mathrm{ml} \cdot$ liter $^{-1}$ to increase the water-holding capacity of the medium.

Comparison of amendments (Expt. 2). Cuttings were planted on 14 June 1989. Materials tested and their rates are presented in Table 3. As in Expt. 1, 3- to 4-month release micro Osmocote and pine needles aged 3 years were tested. Animal feed-grade unsteamed bonemeal of particle size $5.6 \mathrm{~mm}$ and finer (tested in Expt. 1) was compared to a coarser size (9.5 $\mathrm{mm}$ and finer) to determine if the release period could be lengthened.

Nonviable bacteria Brevibacterium lactofermentum (strain A and one that produced a different amino acid, designated "B"), as well as a mixture of two nonviable bacteria, Bacillus licheniformis and Bacillus subtilis, plus the fungus Aspergillus niger were also evaluted. This latter mixture contained diatomaceous earth used as a filtrate in the enzyme production process from 
Table 1. Nutrient sources; $\mathrm{N}$ content of sources; application rate of $\mathrm{N}$ ( $\mathrm{g} \cdot \mathrm{liter}{ }^{-1}$ root medium) for sources; plant ratings at days 27,43, 64, and 76; and end-crop (11 weeks) plant characteristics at day 78 of chrysanthemum plants (Expt. 1).

\begin{tabular}{|c|c|c|c|c|c|c|c|c|c|}
\hline \multirow[b]{3}{*}{ Sources } & \multicolumn{2}{|c|}{ Nitrogen } & \multirow{2}{*}{\multicolumn{4}{|c|}{ Ratings $^{z}$ (week) }} & \multicolumn{3}{|c|}{ Plant } \\
\hline & \multirow{2}{*}{$\begin{array}{c}\text { Content } \\
(\%)\end{array}$} & \multirow{2}{*}{$\begin{array}{c}\text { Applied } \\
\left(\mathrm{g} \cdot \text { liter }^{-1}\right)\end{array}$} & & & & & \multirow{2}{*}{$\begin{array}{c}\mathrm{Ht} \\
(\mathrm{cm})\end{array}$} & \multirow{2}{*}{$\begin{array}{l}\text { Width } \\
(\mathrm{cm})\end{array}$} & \multirow{2}{*}{$\begin{array}{c}\text { Dry wt } \\
(\mathrm{g})\end{array}$} \\
\hline & & & 3 & 6 & 9 & 11 & & & \\
\hline - Controly & -- & 0.00 & 3.3 & 2.3 & 1.7 & 1.0 & 9.0 & 8.6 & 3.8 \\
\hline+ Control $^{x}$ & $\ldots$ & $\cdots$ & 9.3 & 10.0 & 10.0 & 10.0 & 19.3 & 25.7 & 67.1 \\
\hline \multirow[t]{4}{*}{ Micro Osmocote } & 17.00 & 0.15 & 7.7 & 6.3 & 5.7 & 5.2 & 13.1 & 14.1 & 15.8 \\
\hline & & 0.30 & 9.3 & 8.3 & 7.7 & 6.3 & 15.5 & 17.9 & 29.5 \\
\hline & & 0.59 & 9.7 & 8.3 & 8.3 & 7.5 & 17.0 & 20.2 & 42.7 \\
\hline & & 0.89 & 10.0 & 9.7 & 9.7 & 9.0 & 18.6 & 22.9 & 53.4 \\
\hline \multirow[t]{4}{*}{ B. lactofermentum } & 11.21 & 0.17 & 7.7 & 6.7 & 6.3 & 4.8 & 12.4 & 13.8 & 16.3 \\
\hline & & 0.33 & 8.0 & 7.7 & 7.3 & 6.2 & 14.4 & 16.5 & 26.7 \\
\hline & & 0.66 & 8.7 & 9.0 & 9.0 & 7.7 & 13.2 & 19.8 & 42.5 \\
\hline & & 1.00 & 9.7 & 10.0 & $10: 0$ & 9.5 & 13.7 & 23.4 & 53.5 \\
\hline \multirow{5}{*}{$\begin{array}{l}\text { Water-treatment } \\
\text { sludge }\end{array}$} & & & & & & & & & \\
\hline & 1.14 & 0.11 & 6.7 & 6.3 & 5.3 & 4.7 & 9.9 & 15.6 & 7.6 \\
\hline & & 0.21 & 6.7 & 5.7 & 5.0 & 4.2 & 9.0 & 13.3 & 10.7 \\
\hline & & 0.42 & 7.0 & 6.0 & 5.3 & 5.2 & 12.4 & 14.3 & 17.6 \\
\hline & & 0.63 & 8.7 & 7.3 & 7.0 & 6.7 & 14.2 & 16.6 & 28.3 \\
\hline \multirow{4}{*}{ Bonemeal } & 5.55 & 0.21 & 8.0 & 7.3 & 5.7 & 4.2 & 12.2 & 14.1 & 14.6 \\
\hline & & 0.41 & 8.3 & 7.3 & 6.0 & 4.8 & 13.2 & 14.7 & 18.9 \\
\hline & & 0.82 & 8.7 & 9.3 & 8.3 & 6.5 & 15.2 & 17.8 & 30.0 \\
\hline & & 1.23 & 8.7 & 9.3 & 9.0 & 8.0 & 16.3 & 20.4 & 39.9 \\
\hline Pine needles & 0.26 & 0.15 & 6.3 & 4.7 & 3.3 & 2.7 & 9.6 & 12.7 & 6.4 \\
\hline $\operatorname{LSD} \alpha=0.05$ & & & 1.1 & 1.1 & 0.4 & 0.8 & 1.4 & 2.0 & 4.4 \\
\hline
\end{tabular}

${ }^{2} 1=$ death; $10=$ commercially acceptable growth.

'No amendments; no fertilization during crop production.

${ }^{x}$ Received weekly liquid applications of a solution of $17 \mathrm{~mm} \mathrm{NH}_{4}, 26 \mathrm{~mm} \mathrm{NO}_{3}$, and 13 mм K.

Table 2. Carbon : nitrogen ratio and dry bulk density $\left(\mathrm{g} \cdot \mathrm{cm}^{-3}\right)$ of nutrient sources used in Expts. 1 and 2, and $r^{2}$ values from regression analyses of shoot dry weight by $\mathrm{N}$ rate applied for treatments in Expt. 1.

\begin{tabular}{lccc}
\hline \hline Sources & $\begin{array}{c}\mathrm{C}: \mathrm{N} \\
\text { ratio }\end{array}$ & $\begin{array}{c}\text { Dry bulk } \\
\text { density } \\
\left(\mathrm{g} \cdot \mathrm{cm}^{-3}\right)\end{array}$ & $\begin{array}{c}\text { Coefficient of } \\
\text { determination } \\
\left(\mathrm{r}^{2}\right)\end{array}$ \\
\hline B. lactofementum & $4.7: 1$ & 0.55 & 0.97 \\
Bonemeal & $5.2: 1$ & 0.66 & 0.90 \\
Poultry sludge & $8.8: 1$ & 0.64 & --- \\
Feathers & $3.9: 1$ & 0.01 & $\ldots$ \\
Fungus/bacteria mix & $8.0: 1$ & 0.25 & -- \\
Water-treatment & $5.4: 1$ & 0.07 & 0.95 \\
$\quad$ sludge & $63.0: 1$ & 0.12 & $0.13^{2}$ \\
Pine needles & --- & --- & 0.94 \\
Micro Osmocote & &
\end{tabular}

${ }^{2}$ The $r^{2}$ value of the regression of dry weight of above-ground shoots by $\mathrm{N}$ rate of pine needles applied is low because the line, although linear, had almost no slope.

which these microorganisms were derived. The three microorganism sources noted were received as liquid sludges of $5 \%$ to $11 \%$ solids. To prepare for incorporation into the medium, each was poured onto fiberglass trays to a depth of $2.0 \mathrm{~cm}$ and dried in a forced-air oven at $82 \mathrm{C}$. Additionally, a batch of B. lactofermentum, B strain, and a batch of the bacteria plus fungus mixture were dried at $116 \mathrm{C}$ in an attempt to cross-link proteins and prolong the nutrient release of these materials during mineralization.

Other $\mathrm{N}$ sources tested included dried sludge, derived from a poultry manure-methane generator, that had been anaerobically digested (Steinsberger et al., 1987) and ground poultry feathers. Feathers were applied with and without the addition of the viable bacterium B. licheniformis (laboratory of J.C.H. Shih, North Carolina State Univ., Raleigh), which catalyzes the hydrolysis of proteins in feathers. The bacterium is thermophilic, with optimum activity occurring at $50 \mathrm{C}$ and $\mathrm{pH} 7.5$. A water suspension of $10^{7}$ cells $/ \mathrm{ml}$ of the bacterium was incorporated into the feathers by thoroughly handmixing it with the dry feathers at a rate of $1 \mathrm{ml}$ culture to $2 \mathrm{~g}$ feathers.

Two controls were employed. All required nutrients were applied in one control as described in Expt. 1 ( + control). In the second control, all essential nutrients except $\mathrm{N}$ were applied as dolomitic limestone, superphosphate, and FTE-555 micronutrient mix in the root medium and a weekly application of $6.5 \mathrm{~mm} \mathrm{~K}_{2} \mathrm{SO}_{4}$ solution (- control). The last was applied weekly as a thorough watering to all $\mathrm{N}$ source treatments, except micro Osmocote.

Manometers were randomly placed in pots and blocks to represent the range of treatments with different plant growth and media physical properties due to the nutrient source additions. Plants were watered when the average of eight manometer readings was $\approx 300 \mathrm{~cm}$ tension. This guide was, through necessity, not followed before soil solution sampling. The leaching fraction was estimated to fall within the range 0.7-0.8.

\section{Results and Discussion}

Experiment 1. The efficacy, in respect to growth, of the sources at the $\mathrm{N}$ rates applied was in the order $B$. lactofermentum and micro Osmocote > bonemeal > water-treatment sludge > 3year-aged pine needles (Table 1). The linear relationship (Table 2) between dry weight and rate of each source suggested that plants did not achieve maximum potential growth and that higher rates might improve plant response. Plants treated with the high- 
Table 3. Nutrient sources; $\mathrm{N}$ content of sources; application rate of $\mathrm{N}$ (g.liter ${ }^{-1}$ root medium) for sources; plant ratings at days 9, 22, 37, 51, 65, and 86; and end-crop (12 weeks) plant characteristics at day 86 for chrysanthemum plants (Expt. 2).

\begin{tabular}{|c|c|c|c|c|c|c|c|c|c|c|c|}
\hline \multirow[b]{3}{*}{ Sources } & \multicolumn{2}{|c|}{ Nitrogen } & \multirow{2}{*}{\multicolumn{6}{|c|}{ Ratings $^{z}$ (week) }} & \multicolumn{3}{|c|}{ Plant } \\
\hline & \multirow{2}{*}{$\begin{array}{c}\text { Content } \\
(\%)\end{array}$} & \multirow{2}{*}{$\begin{array}{c}\text { Applied } \\
\left(\mathrm{g} \cdot \mathrm{liter}^{-1}\right)\end{array}$} & & & & & & & \multirow{2}{*}{$\begin{array}{c}\mathrm{Ht} \\
(\mathrm{cm})\end{array}$} & \multirow{2}{*}{$\begin{array}{l}\text { Width } \\
\text { (cm) }\end{array}$} & \multirow{2}{*}{$\begin{array}{l}\text { Dry wt } \\
\text { (g) }\end{array}$} \\
\hline & & & 1 & 3 & 5 & 7 & 9 & 12 & & & \\
\hline - Controly & $\cdots$ & 0.00 & 10.0 & 5.0 & 2.7 & 2.3 & 2.0 & 2.0 & 9.2 & 6.9 & 4.0 \\
\hline+ Control $^{x}$ & --- & -- & 10.0 & 10.0 & 10.0 & 10.0 & 10.0 & 9.7 & 25.2 & 26.7 & 48.5 \\
\hline Micro Osmocote & 17.00 & 0.89 & 10.0 & 10.0 & 10.0 & 9.3 & 10.0 & 9.0 & 25.6 & 23.1 & 43.3 \\
\hline \multirow[t]{2}{*}{ B. lactofermentum ${ }^{\mathrm{w}, \mathrm{u}}$} & 11.21 & 0.50 & 10.0 & 9.3 & 9.0 & 8.3 & 7.7 & 7.0 & 22.2 & 18.0 & 31.5 \\
\hline & & 1.00 & 9.7 & 9.0 & 9.0 & 9.3 & 9.3 & 9.0 & 23.7 & 24.1 & 49.5 \\
\hline \multirow[t]{2}{*}{ B. lactofermentum ${ }^{\mathrm{v}, \mathrm{u}}$} & 10.88 & 0.97 & 9.7 & 9.3 & 9.3 & 9.3 & 9.7 & 9.3 & 24.2 & 25.1 & 47.1 \\
\hline & & 1.45 & 9.7 & 9.0 & 9.3 & 9.3 & 9.3 & 9.0 & 24.4 & 24.8 & 47.0 \\
\hline B. lactofermentum ${ }^{\mathrm{v}, \mathrm{t}}$ & 11.82 & 1.05 & 9.3 & 8.3 & 9.3 & 9.0 & 9.0 & 9.0 & 23.4 & 23.6 & 38.4 \\
\hline \multirow[t]{2}{*}{ Feathers ${ }^{\mathrm{s}}$} & 13.09 & 0.97 & 10.0 & 7.7 & 7.0 & 6.7 & 5.7 & 5.0 & 18.2 & 14.9 & 17.8 \\
\hline & & 1.46 & 10.0 & 8.0 & 7.7 & 7.7 & 6.7 & 5.7 & 19.3 & 15.2 & 17.5 \\
\hline Feathers & 12.46 & 0.92 & 9.7 & 7.7 & 6.3 & 6.0 & 5.3 & 5.7 & 16.5 & 12.9 & 14.5 \\
\hline \multirow[t]{2}{*}{ Poultry sludge } & 1.96 & 0.58 & 10.0 & 8.3 & 7.7 & 7.0 & 6.3 & 5.3 & 18.6 & 15.4 & 16.7 \\
\hline & & 0.87 & 10.0 & 9.3 & 8.3 & 8.0 & 7.3 & 6.7 & 21.7 & 18.4 & 24.8 \\
\hline \multirow[t]{2}{*}{ Fungus/bacteria mix } & 3.00 & 0.41 & 10.0 & 7.3 & 6.3 & 5.7 & 5.0 & 4.7 & 16.4 & 11.6 & 11.4 \\
\hline & & 0.62 & 9.7 & 8.0 & 7.3 & 7.0 & 6.7 & 5.7 & 19.5 & 14.6 & 17.5 \\
\hline Fungus/bacteria mix ${ }^{t}$ & 2.93 & 0.40 & 10.0 & 7.7 & 7.0 & 7.0 & 5.7 & 4.7 & 18.3 & 13.5 & 13.0 \\
\hline Pine needles ${ }^{r}$ & 0.26 & 0.80 & 10.0 & 5.3 & 4.0 & 3.3 & 3.0 & 2.3 & 12.5 & 9.2 & 6.4 \\
\hline Bonemieal & 5.55 & 1.23 & 10.0 & 9.3 & 9.3 & 9.0 & 8.3 & 7.7 & 22.4 & 21.8 & 34.9 \\
\hline \multirow[t]{2}{*}{ Coarse bonemeal } & 5.46 & 1.21 & 10.0 & 10.0 & 9.7 & 9.0 & 8.7 & 9.0 & 23.0 & 22.9 & 39.2 \\
\hline & & 1.82 & 10.0 & 9.3 & 9.7 & 9.7 & 9.7 & 9.7 & 24.4 & 25.0 & 44.5 \\
\hline $\operatorname{LSD} \alpha=0.05$ & & & 0.6 & 0.9 & 0.8 & 0.8 & 0.8 & 0.8 & 2.8 & 3.0 & 6.5 \\
\hline
\end{tabular}

${ }^{\mathrm{z}} 1$ = death; 10 = commercially acceptable growth.

${ }^{y}$ Fertilizer, other than $\mathrm{N}$, premixed with medium, plus solution of $\mathrm{K}_{2} \mathrm{SO}_{4}$ weekly.

${ }^{x}$ Received weeky liquid applications of a solution of $17 \mathrm{~mm} \mathrm{NH}_{4}, 26 \mathrm{~mm} \mathrm{NO}_{3}$, and $13 \mathrm{~mm} \mathrm{~K}$.

"Valine strain.

"Isoleucine strain.

"Dried at $82 \mathrm{C}$.

Dried at $116 \mathrm{C}$.

sacillus lichenformis applied.

'Amended with $8.91 \mathrm{~g}$ dolomitic lime/liter and $2.67 \mathrm{~g}$ superphosphate/liter.

${ }^{9}$ Arnended with $5.94 \mathrm{~g}$ dolomitic lime/liter and $1.78 \mathrm{~g}$ superphosphate/liter.

est rate of micro Osmocote or B. lactofermentum produced a quantity of growth similar to that achieved with the + control through 9 weeks, but slowed in growth during the last 2 weeks.

After $\mathrm{N}$ was released from the organic nutrient sources, it had many possible fates, including interception and uptake by the plant, leaching, immobilization, $\mathrm{NH}_{3}$ volatilization, denitrification, and $\mathrm{NH}_{4}$ fixation by vermiculite. Based on $\mathrm{C}$ : $\mathrm{N}$ ratios of sources (Table 2), immobilization of $\mathrm{N}$ by soil microbes was unlikely in all treatments, except pine needles. Ammonia volatilization was probably not a significant reaction given the $\mathrm{pH}$ range of these experiments. The anaerobic conditions required for large $\mathrm{N}$ losses through denitrification were not present, as witnessed by the excellent growth of the + control plants. The sites of vermiculite particles that fix $\mathrm{NH}_{4}$ were likely saturated during the early periods of luxurient $\mathrm{N}$ release, so this would not be a fate of $\mathrm{N}$ late in these experiments. However, significant nutrient leaching and interception by plants were occurring, as discussed later. Although soil solution analyses of $\mathrm{NO}_{3}-\mathrm{N}+$ $\mathrm{NH}_{4}-\mathrm{N}$ could not account for all $\mathrm{N}$ released by the nutrient sources, the data indicated the relative levels of $\mathrm{N}$ being released by the sources at any one time.

In Expt. 1, soil solution analyses indicated that $\mathrm{N}_{\left(\mathrm{N}_{3}-\mathrm{N}+\right.}+$ $\mathrm{NH}_{4}-\mathrm{N}$ ) was not present in significant quantities in the pots of any candidate $\mathrm{N}$ sources after 6 weeks of the cropping cycle (Fig. 1A). Brevibacterium lactofermentum, micro Osmocote, and bonemeal released an adequate amount of $\mathrm{N}$ through 3 weeks of growth, after which $\mathrm{N}$ levels dropped to near $0 \mathrm{mg} \mathrm{N} /$ liter at 6 weeks. Additional $\mathrm{N}$ released after 6 weeks and not found through soil solution analyses was likely intercepted and absorbed by the plants or leached from the pot during watering. This same pattern of rapid initial $\mathrm{N}$ release followed by diminishing $\mathrm{N}$ release was reported by Wright (1978) and King and Vick (1978) in studies with fermentation residues. Waste-water treatment sludge and pine needles initially provided slightly more $\mathrm{N}$ than later in the cropping cycle, but never enough for plant growth. As expected, nearly all of the inorganic $\mathrm{N}$ released from the organic sources was in the ammoniacal form; any $\mathrm{NO}_{3}$ present was formed by subsequent vitrification of $\mathrm{NH}_{4}$ (Fig. 1 B and $\mathrm{C}$ ). The drop in the $\mathrm{N}$ level of the + control at week 6 probably resulted from leaching due to an additional application of water before the solution samples were collected (Fig. 1A).

Midcrop tissue $\mathrm{N}$ levels of plants treated with micro Osmocote or B. lactofermentum were similar and met the minimum critical level of 4\% N (Lunt et al., 1964; Widmer et al., 1989) (Table 4). Plants treated with bonemeal and sludge had lower $\mathrm{N}$ levels. Standards do not exist for the end-crop analysis. However, chrysanthemums treated with any of the sources had a lower $\mathrm{N}$ content than the + control plants, possibly an indication that available $\mathrm{N}$ declined during the second half of the crop. Possibly, the + control tissue N levels were excessive, thus exaggerating the inadequacy of the treatment tissue levels.

Phosphorus was incorporated into the medium before plant- 

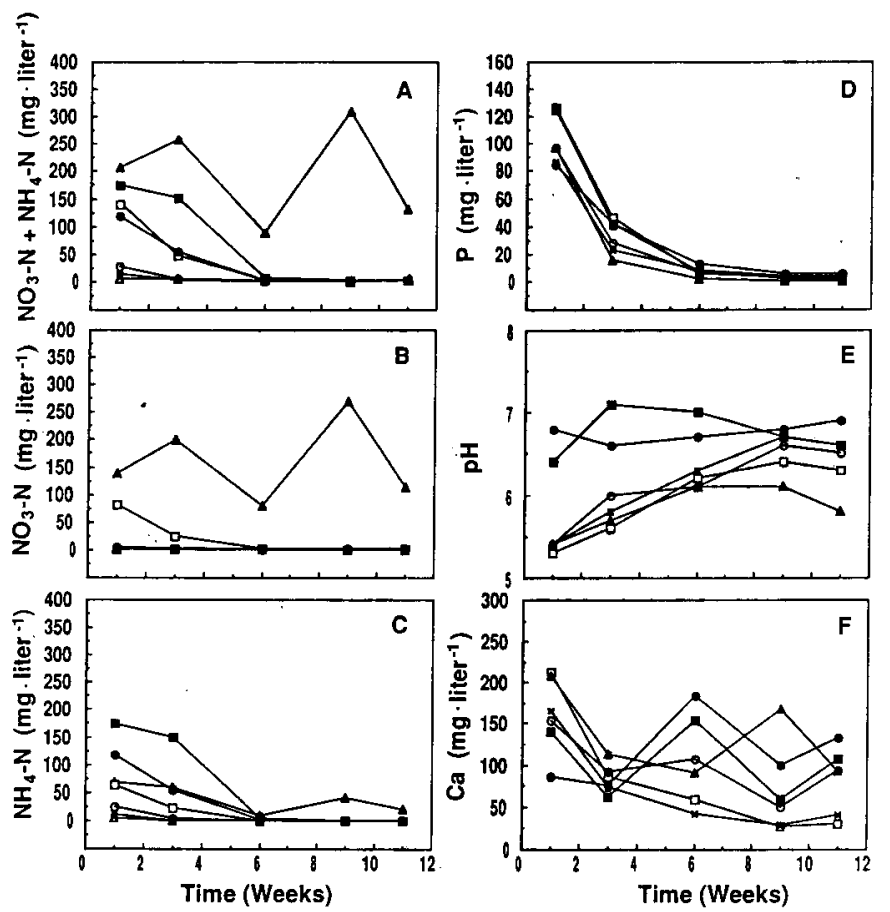

Fig. 1. Mineral nutrient concentrations in the soil solution of root 'media treated with: + control (received weekly liquid applications of a solution of $17 \mathrm{mM} \mathrm{NH}_{4}, 26 \mathrm{mM} \mathrm{NO}_{3}$, and $\left.13 \mathrm{~mm} \mathrm{~K}\right)=\boldsymbol{\Delta}$, control (no amendments, no fertilization during crop production) $=$ $\Delta$, Brevibacterium $=\boldsymbol{\square}$, micro Osmocote $=\square$, bonemeal $=\boldsymbol{0}$, water treatment sludge $=\mathrm{O}$, pine needles aged 3 years $=\mathrm{x}$ at the highest applied $\mathrm{N}$ rate of each in Expt. 1. (A) total $\mathrm{N}$ as $\mathrm{NO}_{3}-\mathrm{N}+$ $\mathrm{N} \mathrm{H}_{4}-\mathrm{N},(\mathrm{SE}=$ means \pm 12.7$) ;($ B $) \mathrm{N} \mathrm{O}_{3}-\mathrm{N},(\mathrm{SE}=$ mean \pm 9.4$)$; (C) $\mathrm{NH}_{4}-\mathrm{N}$, (SE = mean \pm 4.7$)$; (D) $\mathrm{PO}_{4}-\mathrm{P},(\mathrm{SE}=$ mean \pm 6.2$)$; (E) $\mathrm{pH}(\mathrm{SE}=$ mean \pm 0.1$)$; and $(\mathbf{F}) \mathrm{Ca}(\mathrm{SE}=$ mean \pm 12.8$)$.

ing. Plots of soil solution P concentrations (Fig. ID) show that $P$ levels were high for all treatments during the first week, decreased rapidly until week.6, and thereafter continued to slowly decline. Elevated levels of soil solution $\mathrm{P}$ resulted from the micro Osmocote and B. lactofermentum sources during the first 3 weeks and from bonemeal during weeks 6 to 11. Phosphorus levels were adequate in all treatments; levels in tissue at midcrop fell within the acceptable range of $0.26 \%$ to $1.15 \%$ (Lunt et al., 1964; Widmer et al., 1989), and were above the + control level at end-crop harvest (Table 4).

The soil solution $\mathrm{pH}$ of the + control rose from $<5.5$ at week 1 to 6.1 at week 9, presumably as a result of limestone dissolution (Fig.1E). After 9 weeks, the $\mathrm{pH}$ declined, probably as a consequence of acidifying effects of nutrient uptake from the weekly fertilizer applications. Root medium $\mathrm{pH}$ levels were similar for the + control, micro Osmocote, waste-water treatment sludge, and pine needles for 6 weeks, after which time the $\mathrm{pH}$ levels were higher in all treatments than in the + control. The $\mathrm{pH}$ of the soil solution of the B. lactofermentum treatments rose to $>7$ during the first 3 weeks of the experiment, then declined slowly to $\approx 6.6$ at harvest during week 11 . Bonemeal also increased solution $\mathrm{pH}$, to 6.9 , during the 1 l-week cropping cycle. Calcium and $\mathrm{Mg}$ levels in root medium treated with $B$. lactofermentum or bonemeal were similar to those of the control over the course of the experiment. This result indicates that the $\mathrm{pH}$ increase was not due to $\mathrm{Ca}$ or $\mathrm{Mg}$ displacement of $\mathrm{H}^{+}$from exchange sites followed by leaching of $\mathrm{H}^{+}$from the substrate but more likely was due to the release of $\mathrm{NH}_{3}$ during ammon- ification. Data are shown for Ca (Fig. 1G) but not for $\mathrm{Mg}$, because curves for both elements had similar shapes and relationships. Midcrop foliar analysis (Table 4) indicated that $\mathrm{Ca}$ and $\mathrm{Mg}$ levels were adequate in all treatments, except wastewater treatment sludge, for which plant tissue levels were significantly lower than in all other treatments. The pronounced increase in $\mathrm{pH}$ resulting from hydrolysis of $\mathrm{NH}_{3}$ mineralized from organic nutrient sources could be compensated for by adjusting the level of limestone initially added to the growing medium.

A comparison of plants treated with waste-water treatment sludge and $B$. lactofermentum, both applied at $\approx 0.6 \mathrm{~g} \mathrm{~N} /$ liter (Table 1), showed that by the 6th week of production, the former had slowed in growth compared with those treated with $B$. lactofermentum. The $\mathrm{C}: \mathrm{N}$ ratios of the sources were similar (Table 2), so an immobilization of $\mathrm{N}$ could not have accounted for the differences in $\mathrm{N}$ efficiency. Thus, the type of microorganism used as the $\mathrm{N}$ source was important, with $B$. lactofermentum alone proving to be the best in this study. Sludge provided a high but safe level of $\mathrm{Mn}$ that resulted in low tissue levels of $\mathrm{Fe}$ at mid- and end-crop harvests (Table 4). The use of this sludge would warrant application of additional $\mathrm{Fe}$.

The 3-year-aged pine needles applied at $0.15 \mathrm{~g} \mathrm{~N} /$ liter produced plants vastly inferior to those treated with $B$. luctofermentum at $0.17 \mathrm{~g} \mathrm{~N} /$ liter or with micro Osmocote at $0.15 \mathrm{~g} \mathrm{~N} /$ liter (Table 1) due to $\mathrm{N}$ immobilization, as suggested by the $\mathrm{C}$ : $\mathrm{N}$ ratio of 63.0:1 (Table 2). Plants in other treatments involving pine needles at rates down to $0.04 \mathrm{~g} \mathrm{~N} /$ liter and 1 or 3 years of aging led to similar growth. (data not shown).

For the midcrop foliar analysis, $\mathrm{Cu}$ and $\mathrm{S}$ levels appeared adequate. The final foliar analysis indicated that the levels of all elements occurred in appropriate balance, with the exception of the $\mathrm{Fe}: \mathrm{Mn}$ ratio in the water-treatment sludge plants, as described earlier. The midcrop foliar K levels (Table 4) were adequate since concentrations of all treatments fell within the range $3.5 \%$ to $10.0 \%$ recommended for chrysanthemums by Lunt et al. (1964) and Widmer et al. (1989).

Experiment 2. The best preplant $\mathrm{N}$ sources were B. lactofermentum, bonemeal, and micro Osmocote. Coarse bonemeal at $1.82 \mathrm{~g} \mathrm{~N} /$ liter, micro Osmocote at $0.89 \mathrm{~g} \mathrm{~N} /$ liter, B. lactofermentum (A strain) at $1.00 \mathrm{~g} \mathrm{~N} /$ liter, and B. lactofermentum (B strain) at 0.97 and $1.45 \mathrm{~g} \mathrm{~N} /$ liter all produced plants that were not significantly different from the + control through 12 weeks (Table 3). The equal response of plants to B. lactofermentum (B strain) applied at 0.97 and $1.45 \mathrm{~g} \mathrm{~N} /$ liter indicates that maximum response was also achieved at the $1.00 \mathrm{~g}$ N/liter rate applied in Expt. 1. No appreciable amount of $\mathrm{N}$ was found in the soil solution of any treatments after 7 weeks (Fig. 2), indicating that higher initial rates did not prolong the period of $\mathrm{N}$ availability.

At midcrop, the $\mathrm{N}$ concentrations in plants treated with $B$. lactofermentum, bonemeal, or micro Osmocote at rates $>0.89$ g N/liter were higher than the minimum critical level of $4 \% \mathrm{~N}$. None of the B.lactofermentum treatments resulted in significantly different $\mathrm{N}$ contents than the + control $(6.44 \%)$ (Table 5). As in Expt. 1, the primary form of inorganic $\mathrm{N}$ resulting from organic souces was $\mathrm{NH}_{4}$ (data not shown). Soil solution $\mathrm{pH}$ was higher in the B. lactofermentum and bonemeal treatments without any associated rise in $\mathrm{Ca}$ or $\mathrm{Mg}$ (data not shown).

As in Expt. 1, quality and size of plants treated with high rates of B. lactofermentum and bonemeal were maintained beyond the time that appreciable $\mathrm{N}$ was found in the soil solution and were similar to the + control at end crop (Table 3). Total 
Table 4. Mineral content (dry-weight basis) of the youngest fully expanded leaves collected at midcrop (day 48) and of whole above-ground plant tissue at end crop (day 78) from plants treated with the highest rate of each source (Expt. 1).

\begin{tabular}{|c|c|c|c|c|c|c|c|c|c|c|c|}
\hline \multirow[b]{3}{*}{ Source } & \multirow{3}{*}{$\begin{array}{c}\mathrm{N} \\
\text { applied } \\
\left(\mathrm{g} \cdot \mathrm{liter}^{-1}\right)\end{array}$} & \multicolumn{10}{|c|}{ Mineral } \\
\hline & & $\mathbf{N}$ & $\mathbf{P}$ & $\mathbf{K}$ & $\mathrm{Ca}$ & $\mathrm{Mg}$ & $S$ & $\mathrm{Fe}$ & $\mathrm{Mn}$ & $\mathrm{Zn}$ & $\mathrm{Cu}$ \\
\hline & & \multicolumn{6}{|c|}{$\%$} & \multicolumn{4}{|c|}{$\mu \mathrm{g} \cdot \mathrm{g}^{-1}$} \\
\hline \multicolumn{12}{|c|}{ Midcrop } \\
\hline+ Control $^{x}$ & -- & 5.45 & 0.32 & 5.7 & 1.2 & 0.42 & 0.36 & 83 & 225 & 360 & 13 \\
\hline Micro Osmocote & 0.89 & 3.95 & 0.90 & 4.6 & 1.3 & 0.43 & 0.47 & 109 & 253 & 330 & 13 \\
\hline B. lactofermentum & 1.00 & 4.31 & 0.86 & 5.5 & 0.8 & 0.28 & 0.76 & 80 & 254 & 337 & 15 \\
\hline \\
\hline sludge & 0.63 & 2.33 & 0.91 & 3.9 & 0.6 & 0.17 & 0.35 & 49 & 309 & 292 & 14 \\
\hline Bonemeal & 1.23 & 3.05 & 1.00 & 4.7 & 0.8 & 0.24 & 0.49 & 66 & 126 & 146 & 13 \\
\hline \multirow[t]{2}{*}{ LSD $\alpha=0.05$} & & 0.38 & 0.14 & 0.6 & 0.1 & 0.04 & 0.05 & NS & 45 & 49 & 4 \\
\hline & \multicolumn{10}{|c|}{ End crop } & \\
\hline+ Contr & -- & 3.11 & 0.22 & 4.4 & 0.8 & 0.30 & 0.23 & 86 & 156 & 285 & 10 \\
\hline Micro Osmocote & 0.89 & 1.94 & 0.48 & 3.7 & 1.0 & 0.32 & 0.24 & 86 & 183 & 245 & 11 \\
\hline B. lactofermentum & 1.00 & 1.71 & 0.46 & 4.9 & 0.9 & 0.28 & 0.32 & 80 & 175 & 237 & 10 \\
\hline \multirow{2}{*}{\multicolumn{12}{|c|}{$\begin{array}{l}\text { Water-treatment } \\
\text { sludge }\end{array}$}} \\
\hline & 0.63 & 1.48 & 0.57 & 4.0 & 1.0 & 0.25 & 0.23 & 43 & 260 & 374 & 13 \\
\hline Bonemeal & 1.23 & 1.45 & 0.58 & 3.8 & 1.0 & 0.25 & 0.29 & 36 & 117 & 136 & 9 \\
\hline Pine needles & 0.15 & 0.77 & 0.60 & 2.8 & 1.2 & 0.32 & 0.30 & 76 & 446 & 233 & 10 \\
\hline LSD $\alpha=0.05$ & & 0.17 & 0.13 & 0.9 & 0.2 & 0.07 & 0.03 & 22 & 64 & 76 & NS \\
\hline
\end{tabular}

${ }^{2}$ Received weekly liquid applications of a solution of $17 \mathrm{mM} \mathrm{NH}_{4}, 26 \mathrm{mM} \mathrm{NO}_{3}$, and 13 mм K.

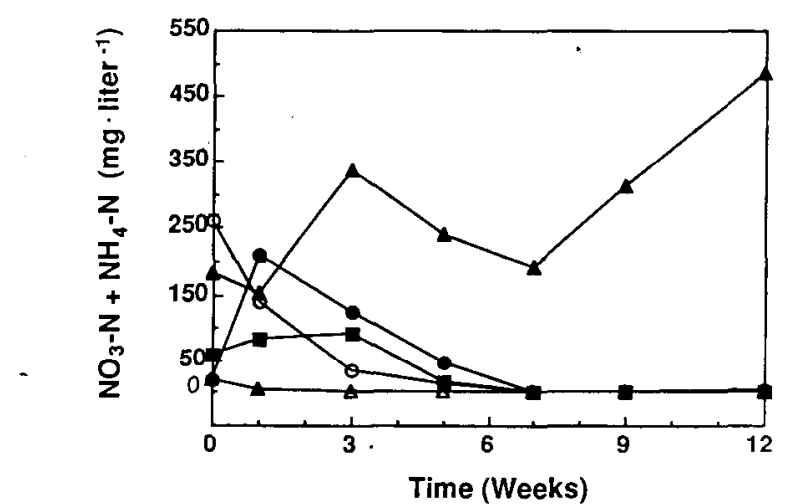

Fig. 2. Total $\mathrm{N}\left(\mathrm{NO}_{3}-\mathrm{N}+\mathrm{NH}_{4}-\mathrm{N}\right)$ concentrations in the soil solution of root media treated with the test materials that performed best in Expt. $2(+$ control $=\boldsymbol{\Delta},-$ control $=\Delta$, micro Osmocote $=\bigcirc$, Brevibacterium $=\boldsymbol{\square}$, bonemeal $=1)$. $\mathrm{SE}=$ mean \pm 25.9 .

$\mathrm{N}$ content of the soil solution was determined in the B. lactofermentum treatments by Kjeldahl analysis to determine if $\mathrm{N}$ was present and available for plant uptake in a form other than $\mathrm{NO}_{3}$ and $\mathrm{NH}_{4}$, such as amino acids. A low, persistent level of inorganic $\mathrm{N}^{4}=1$ to $5 \mathrm{mg} \cdot$ liter $\left.^{-1}\right)$ was present in all treatments. Analysis of inorganic plus organic $\mathrm{N}$ by the Kjeldahl procedure (data not shown) did not result in concentrations that differed significantly from those for $\mathrm{NO}_{3}-\mathrm{N}$ plus $\mathrm{NH}_{4}-\mathrm{N}$ alone (Fig. 2). Plant growth that occurred during the last weeks of the cropping cycle, after. only low $\mathrm{N}$ levels were found in the soil solution, could have been due to luxury consumption of $\mathrm{N}$ during the first 7 weeks, followed by translocation during the final 5 weeks of growth. Plants possibly absorbed $\mathrm{N}$ just as it was released from the sources; this possibility, along with the leaching of $\mathrm{N}$ $1.5 \mathrm{~h}$ before sampling, could account for the low levels of $\mathrm{N}$ present in solution samples.

Plant response to micro Osmocote at $0.89 \mathrm{~g} \mathrm{~N} /$ liter and $B$. lactofermentum (B strain) at $0.97 \mathrm{~g} \mathrm{~N} /$ liter was similar. Thus, an organic $\mathrm{N}$ source that provided mainly $\mathrm{NH}_{4}(B$. lactofermentum) compared favorably with an inorganic $\mathrm{N}$ source that provided $\mathrm{NO}_{3}$ and $\mathrm{NH}_{4}$ (micro Osmocote).

The A strain of B. lactofermentum at $1.00 \mathrm{~g} \mathrm{~N} /$ liter and the B strain at $0.97 \mathrm{~g} \mathrm{~N} /$ liter resulted in similar quality and growth throughout the crop (Table 3). In addition, the $\mathrm{N}$ content of the plant tissue treated with the different strains did not significantly differ at mid- or end-crop harvest (Table 5; end-crop data not shown), indicating that different $B$. lactofermentum strains have similar efficacy.

Increasing the drying temperature from 82 to $116 \mathrm{C}$ did not improve the efficacy of $B$. lactofermentum (B strain), plant ratings, heights, widths, and $\mathrm{N}$ contents being similar. However, the dry weight of plants fertilized with bacterium dried at 116C was lower than that of plants fertilized with bacterium dried at 82C (Table 3). Drying temperature had no significant effect on the behavior of the bacteria plus fungus mix.

Plants treated with feathers with and without the hydrolyzing bacterium $B$. licheniformis at 0.97 and $0.92 \mathrm{~g} \mathrm{~N} /$ liter were rated and grew similarly, but were rated lower and grew less than plants treated with B. lactofermentum at $0.97 \mathrm{~g} \mathrm{~N} /$ liter (Table 3). Increasing the $\mathrm{N}$ rate of feathers plus hydrolyzing bacterium from 0.97 to $1.46 \mathrm{~g} \mathrm{~N} /$ liter did not improve plant response, and $\mathrm{N}$ was not released from any feather application after the 3rd week (Fig. 3). The hydrolyzing bacterium is a thermophilic organism with optimum temperature and $\mathrm{pH}$ requirements of $50 \mathrm{C}$ and 7.5 , respectively. The root medium temperature and $\mathrm{pH}$ regime may have been too low to maintain bacterium viability.

Anaerobic poultry sludge did not produce quality plants at the $\mathrm{N}$ rates applied. Growth of plants treated with the sludge at $0.87 \mathrm{~g} \mathrm{~N} /$ liter was similar to that of plants treated with $B$. lactofermentum (A strain) at $0.50 \mathrm{~g} \mathrm{~N} /$ liter (Table 3). A comparison of anaerobic poultry sludge applied at $0.58 \mathrm{~g} \mathrm{~N} /$ liter and $B$. lactofermentum (A strain) at $0.50 \mathrm{~g} \mathrm{~N} / \mathrm{liter}$, a more equivalent comparison, indicated that the efficiency of $\mathrm{N}$ use was superior 
Anaerobic poultry sludge derived from poultry manure was a good source of $\mathrm{P}$, releasing a greater quantity than either micro Osmocote or the + control (Fig. 5). Superphosphate was added in equal quantity to the anaerobic poultry sludge and to the + control root medium, but more $\mathrm{P}$ was released from the anaerobic poultry sludge, indicating that dried, anaerobic sludge from a poultry manure-methane generator was an effective organic P-fertilizer alternative.

Although the medium of the pine needle treatment consisted entirely of 3-year-aged needles that provided $0.80 \mathrm{~g} \mathrm{~N} / \mathrm{liter}$, plant growth was very poor (Table 3). Much of the $\mathrm{N}$ in the pine needles was immobilized and unavailable for plant uptake (Table 2). Also, the $100 \%$ pine needle substrate, due to its coarse texture, may have provided unfavorable physical properties for plant growth.

Coarse bonemeal applied at $1.82 \mathrm{~g} \mathrm{~N} /$ liter resulted in growth almost equivalent to the + control (Table 3 ). Coarse and regular particle-sized bonemeal applied at $1.21 \mathrm{~g} \mathrm{~N} /$ liter and $1.23 \mathrm{~g} \mathrm{~N} /$ liter, respectively, resulted in similar growth, but less than coarse bonemeal applied at $1.82 \mathrm{~g} \mathrm{~N} /$ liter. In unsteamed bonemeal. $\mathrm{N}$ is contained in the porous bone marrow in the form of 'the protein collagen. Particle size had little effect on $\mathrm{N}$ availability because the marrow was probably easily accessed by soil solution.

Results of both experiments indicated that dried $B$. lactofermentum, unsteamed bonemeal, and micro Osmocote provided adequate root medium $\mathrm{N}$ levels for plant growth through 6 to 7 weeks, and plant growth was similar to that of the + control through 9 to 12 weeks. Nutrient release did not follow the desired low and steady pattern. Instead, it was higher than desired during the initial weeks and low during the latter weeks of the cropping cycle. This downward shift of concentration could have resulted in periods of inadequate $\mathrm{N}$ accumulation by the plants during the time required for the $\mathrm{N}$ uptake kinetics of the plant to shift to the lower external $\mathrm{N}$ concentration, i.e., for the $\mathrm{K}_{\mathrm{m}}$

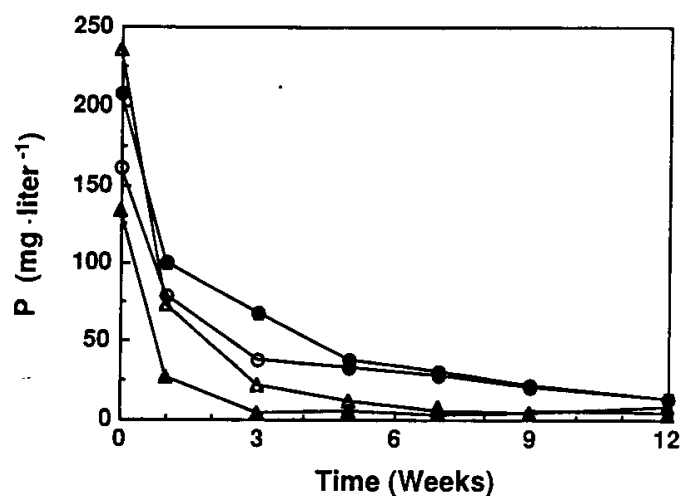

Fig. 5. Phosphorus concentrations in the soil solution of root media treated with superphosphate $(+$ control $=\boldsymbol{\Delta})$, anaerobic poultry sludge (at $0.58 \mathrm{~g} \mathrm{~N} /$ liter $=\mathrm{O}$ or at $0.87 \mathrm{~g} \mathrm{~N} /$ liter $=\mathbf{0}$ ), or micro Osmocote $(\Delta)$ in Expt. 2. $\mathrm{SE}=$ mean \pm 12.8 . to decrease and the $\mathrm{V}_{\max }$ to increase (Glass, 1989). Establishing and sustaining low $\mathrm{N}$ levels in the soil solution from organic sources is more dependent on the extent and/or rate of $\mathrm{N}$ release than on the amount of $\mathrm{N}$ applied. Thus, it may be possible to alter organic materials to effect a constant $\mathrm{N}$ release over an extended period, or perhaps to effect a steadily increasing rate of release over time to meet the needs of increasing plant biomass production.

\section{Literature Cited}

Bunt, A.C. 1988. Media and mixes for container-grown plants. Unwin Hyman, London. p. 105.

Cataldo, D.A., M. Haroon, L.E. Schrader, and V.L. Youngs. 1975. Rapid calorimetric determination of nitrate in plant tissue by nitration of salicylic acid. Commun. Soil Sci. Plant Anal. 6:71-80.

Chancy, A.L. and E.P. Marbach. 1962. Modified reagents for determination of urea and ammonia. Clinical Chem. 8:130-132.

Chapman, H.D. and P.F. Pratt. 1961. Methods of analysis for soils, plants, and waters. Univ. of California, Riverside, Div. Agr. Sci.p. $169-170$.

Clement, C. R., M.J. Hopper, R.J. Canaway, and L. Jones. 1974. A system for measuring the uptake of ions by plants from flowing. solutions of controlled composition. J. Expt. Bot. 24:81-99.

Cox, D.A. 1985. Nitrogen recovery by seed geranium as influenced by nitrogen source. HortScience 20:923-925.

Eastin, E.F. 1978. Total nitrogen determination for plant material containing nitrate. Anal. Biochem. 85:591-594.

Elliot, G.C. and P.V. Nelson. 1983. Relationships among nitrogen accumulation, nitrogen assimilation, and plant growth in chrysanthemums. Physiol. Plant. 57:250-259.

Fonteno, W.C. and P.V. Nelson. 1990. Physical properties of and plant responses to rockwool-amended media. J. Amer. Soc. Hort. Sci. 115:375-381.

Glass, A.D.M. 1989. Plant nutrition: An introduction to current concepts. Jones and Bartlett, Boston. p. 131-132.

Hershey, D.R. and J.L. Paul. 1982. Leaching-losses of nitrogen from pot chrysanthemums with controlled-release or liquid fertilization. Scientia Hort. 17:145-152.

King, L.D. and R.L. Vick, Jr. 1978. Mineralization of nitrogen in fermentation residue from citric acid production. J. Environ. Quality 7:315-318.

Lunt, O. R., A.M. Kofranek, and J.J. Oertli. 1964. Some critical nutrient levels in Chrysanthemum $\times$ morifolium, cultivar Good News, p. 398-413. In: C. Bould, P. Prevot, and J.R. Magness (eds.). Plant analysis and fertilizer problems. IV. W.F. Humphrey, Geneva, N.Y.

Murphy, J. and J.F. Riley. 1962. A modified single solution method for the determination of phosphate in natural waters. Anal. Chim. Acts 27:31-36.

Steinsberger, S. C., J.F. Ort, and J.C.H. Shih. 1987. Composition and phosphorus bioavailability of a solid by-product from anaerobically digested waste from caged layer hens. Poultry Sci. 66:634-639.

Widmer, R. E., J.M. Dole, and H.F. Wilkins. 1989. Tissue analysis standards. GrowerTalks 53(4):21.

Williams, D.E. 1961. The absorption of potassium as influenced by its concentration in the nutrient medium. Plant \& Soil 15 :387-399.

Wright, W.R. 1978. Laboratory and field mineralization of nitrogen from fermentation residues. J. Environ. Quality 7:343-346. 